\title{
THE STUDY OF SYNTACTIC AND SEMANTIC FEATURES OF VERBS IN PROBLEM STATEMENT SECTION OF MASTER THESES
}

\author{
Seyed Foad EBRAHIMI ${ }^{1}$ \\ Mansoor HOSSEINZADEH ${ }^{2}$ \\ English Department, Shadegan Branch, \\ Islamic Azad University, Shadegan, Iran \\ ${ }^{1}$ seyedfoade@gmail.com*
}

Manuscript received 20 April 2018

Manuscript accepted 25 November 2018

\begin{abstract}
The present study was carried to investigate the realisation of verbs in problem statement of English Language Teaching (ELT) theses. To reach this objective, 40 ELT theses, were chosen from reliable databases (ProQuest). The corpus was read carefully to identify the grammatical verbs. Then, the identified verbs were classified based on tenses, aspects and voices. Tenses comprise three tenses of present, past and future. Aspects consist of simple, progressive and perfect. Voices can be either active or passive. To analyse the data for the semantic meanings of the identified verbs, Biber et al.'s (1999) classification was used. After scrutinising the problem statements of forty theses, the data, it was found that the verbs of different tenses, aspects, voices and semantic meanings were used. The findings were discussed to give a clear picture of how verbs are used in problem statements of theses written by native writers of English. The findings may help instructors to equip their students with the ability to use the verbs appropriately in writing the problem statement of their theses.
\end{abstract}

Keywords: Problem statement, thesis, verb, semantic meaning, syntactic feature

\section{Introduction}

In students' educational process, thesis is the final stage of the Master's degree and provides students with the opportunity to show that they have gained the necessary skills and knowledge in order to organise and conduct a research project. It should demonstrate that they are skilled in identifying an area, or areas, suitable for research: setting research objectives; locating, organising and critically analysing the relevant secondary data and authoritative literature; devising an appropriate 
research methodology; analysing the primary data selected and drawing on the literature in the field; drawing conclusions; and if appropriate making relevant recommendations and indications of areas for further research. In the first chapter of a thesis, writers usually have to state the problem that motivates them to conduct the study. Thus, problem statement (PS) acts as an anchor point in a thesis that other parts of thesis should be linked to. The PS has the purpose of convincing the advisory committee and examiners about the importance of topic under investigation. Creswell (2012) points out that the PS section is a part of thesis that contains the topic of the study, the research problem and its justification is based on the existing literature deficiencies or shortcomings, and the importance of addressing a problem for diverse audiences. According to Metoyer-Duran and Hernon (1994), PS serves the function of "crystallizing the issue, the essence of what I am doing" (p. 107). Karbach (2010, p. 89) declares that the writer is required to introduce an academic problem and answer the question "What I want to prove?" Nenty (2009) points that everything in the study has to be a presentation, exploration or proof of the problem. She adds that "the heart of any research project is the problem" and "researchers get off a strong start when they begin with an unmistakably clear statement of the problem" (p. 21). The importance of PS requires the writers to write it in a clear and understandable way. Due to the importance of PS in thesis writing, the present study aims to investigate the syntactic and semantic features of verbs used in PS of thesis written by native writers of English.

\section{Literature Review}

Although the PS is a pivotal section in a thesis, there are rather limited studies on this section (Jalilifar, Firuzmand, \& Roshani, 2011; Ibrahim \& Nambiar, 2011; Nimehchisalem, Tarvirdizadeh, Pidary, \& Nur Izyan, 2016). Jalilifar et al. (2011) studied the rhetorical structure of PS in theses and proposals in the discipline of applied linguistics. They analysed 100 PS sections using Swales' (1990) CARS model. They found that only three steps in the CARS model were treated as optional while others were considered obligatory. The optional steps were claiming centrality, outlining purposes, and question raising. Ibrahim and Nambiar (2011) focused on PS in ESL postgraduate students' writing of proposals or thesis. Their data collection was through semi-structured questionnaires, interviews and document analysis. Their findings highlighted the difficulty students faced in reading and synthesising previous studies. Their problem was mostly in finding the main point of earlier studies and paraphrasing them. They concluded that the problems reported in their study originated from rhetorical structure differences between L1 and English. Nimehchisalem et al. (2016) studied the PS section of Iranian Master Degree theses for the rhetorical structure using CARS model (Swales, 1990). Their analysis of 30 PSs written by TEFL Iranian students suggested that students have problems in presenting the significance of their study in the PS section. They pointed out that lack of awareness of the rhetorical structure of the PS could be the source for the problems of Iranian TEFL students' PS. 
Based on the review of previous studies, there is still a gap of knowledge that needs to be focused on as the main focus in the literature was on the rhetorical structure of PS and linguistic features of this section have been neglected. Thus, this study aims to explore the syntactic and semantic features of verbs used in the PS sections of theses from discipline of English Language Teaching (ELT). Therefore, this study addressed the following questions:

(1) What are the syntactic features of verbs used in the PS part of theses written by native writers of English?

(2) What are the semantic meanings of verbs used in the PS part of theses written by native writers of English?

The focus on verbs is significant because of their complexity in both syntactical and semantic features, which makes them challenging for non-native speakers (English as a second or foreign language) to learn and use in theses (Holmes, 1983, 1988; Stubbs, 1985). In this regard, Waard and Pander Maat (2012) point that the focus on verb is pivotal in academic writing as it can act as a differentiating feature between texts pertaining to experimental results and texts pertaining to more abstract concepts. Thus, this study is significant since the researcher is going to investigate the types of verbs used in the PS of theses.

\section{Methodology}

\section{Corpus}

The corpus used for this study consisted of 40 ELT theses written by native writers of English. A comprehensive list of different theses published in the field of ELT from 2011-2016 were selected from Proquest database. Of these, 40 ELT theses which had been examined in a university in located in countries in which English is the mother tongue were selected. From each thesis, the PS section was chosen for analysis of how verbs were utilised. To make the corpus data comparable, all the chosen theses were matched in length.

\section{Analysis Framework}

The PSs were analysed for syntactic features that include tense, aspect, and voice of verbs. Tense comprises the three tenses of present, past and future. Aspect consists of simple, progressive and perfect. Voice can be either active or passive. The selections of these syntactic features are due to that these features are mostly mentioned in writing instructions on academic writing (Hinkel, 2004). Beason and Laster (2000), in their guide to grammar and usage of features in academic writing, provided a description of tense, and Axelord and Cooper (2001) devoted five pages to the use of tense and voice in their popular textbook for academic writing.

To analyse the corpus for the semantic meanings of the main verbs used in the PS section of theses, Biber et al.'s (1999) classification was used. This 
classification includes a broad range of semantic meanings (Zhang, 2015). Their classification includes seven semantic domains as follows:

1) Activity verbs which are concerned with what people do (e.g., use, give, make, build, perform, measure)

2) Communication verbs involving such communication activities as speaking and writing (e.g., describe, discuss, debate, argue, introduce, suggest)

3) Mental verbs describing cognitive states and activities (e.g., know, believe, remember, understand, consider, design, study, investigate), which also include attitudinal or emotional states (e.g., prefer, love, enchant)

4) Verbs of existence or relationship denoting a relation or a state exists between entities (e.g., include, represent, define, link, associate, relate, influence)

5) Verbs of facilitation or causation indicating a new state of affairs brought about (e.g., cause, allow, require, need, influence)

6) Verbs of simple occurrence reporting the occurrence of events (e.g., develop, grow, increase, and change)

7) Aspectual verbs denoting the stage of progress of events or activities (e.g., keep, continue, and hold)

The data were analysed for frequency of tense, aspect and voice. Following this, the main verbs were analysed for their semantic meanings. A sample of 20 theses was checked by two experts in the area of ELT, in order to increase the reliability and validity of analysis.

\section{Results and Discussion}

Table (1) presents basic results about the verbs includes the frequency and percentage of verbs in terms of tense.

Table 1

Frequency of the tense of verbs

\begin{tabular}{rcc}
\hline & Frequency & Percentage \\
\hline Future & 23 & $5 \%$ \\
Past & 81 & $17 \%$ \\
Present & 365 & $78 \%$ \\
\hline Total & 469 & 100.0 \\
\hline
\end{tabular}

Table 1 shows that 469 verbs were used in 40 theses (PS), of which 365 $(78 \%)$ were the present tense, $81(17 \%)$ were the past tense and $23(5 \%)$ of the verbs were the future tense. The prevalence of the simple tense could be because of acknowledging ventures in postulations, for example, making theme speculations, showing the examination hole, sketching out purposes, illustrating vital discoveries and suggestions, and demonstrating the proposals structure (Examples 1-5). 
Example 1: While much of what we learn about our world comes through visual means, in education people still give precedence to verbal communication.

Example 2: Words and numbers are rigid and specific, but creative individuals convey their inner visual concepts in diverse ways.

Example 3. Despite these possibilities, English/language arts teachers are reticent to instruct their students in the non-verbal skills in which they themselves have little training.

Example 4: However, it seems that even after 10 years of English teaching in the elementary school, concerns surrounding teacher qualifications in English teaching are still very strong, particularly those related to teachers' lack of English language proficiency.

Example 5: These inconsistent findings suggest a need for further research on the relationship between the two, instead of simply assuming a causal relationship as in the previous studies in TESOL.

The second most common tense in PS of ELT theses was the past simple because thesis writers mostly construct their studies on previous ones, and seek gaps in the existing literature (Examples 6-7).

Example 6: As a result of such sociopolitical atmosphere, despite strong debates on its appropriateness and effect, English was introduced into the elementary schools in 1997 by lowering the grade level for beginning English education at school from grade seven to grade three

Example 7: Ferris and Hedgcock (2005) explained that:.....

Table (2) presents basic results about the verbs includes the frequency and percent of verbs in terms of voice.

Table 2

Frequency of the voice of verbs

\begin{tabular}{rcc}
\hline & Frequency & Percentage \\
\hline Perfect & 64 & $14 \%$ \\
\hline Simple & 405 & $86 \%$ \\
\hline Total & 469 & 100.0 \\
\hline
\end{tabular}

Table 2 shows 469 verbs were used in 40 theses (statement of the problem part), of which 405 (86\%) were simple verbs, 64 (14\%) used the perfect tense. The frequent use of the present perfect in ELT theses suggests these writers' preference for claiming the centrality of their study. They also prefer to convince editors and reviewers that the investigated topic has been the concern of researchers over a period of time (Examples 8-11).

Example 8: As mentioned previously, NCTE and IRA (1996) have recognized the need to teach visual literacy in the English/language arts classroom.

Example 9: In addition many states, including Kansas, have included visual literacy in their English/language arts standards and their standards for licensure in English/language arts. 
Example 10: Since 1994, when the seventh government had stated its national policy as saekyehwa [internationalization or globalization], the Korean government has emphasized that Korean people should develop the ability to communicate in English.

Example 11: To be fair, in order to address this problem, the government has provided in-service training programs on English teaching (e.g., 120-hour basic program, 60 hours or more advanced program, overseas training) since 1996.

As shown in Table 3, 469 verbs were used in 40 theses (statement of the problem part), of which 415 (88\%) were active verbs and 54 (12\%) were passive verbs. In this respect, Mohsenzadeh and Ebrahimi (2017) stated that active verbs express meaning more emphatically and vigorously than their weaker counterparts, verbs in the passive voice, which lack strength because their subjects receive the action instead of doing it. The lower incidence of the passive voice might suggest that in much scientific writing, the passive voice properly puts the emphasis on the experiment, participants, or process being described, not on the researcher (Mohsenzadeh \& Ebrahimi, 2017). Examples 12 to 13 show the use of the passive voice.

Table 3

Frequency of passive and active voices

\begin{tabular}{lcc}
\hline & Frequency & Percentage \\
\hline Active & 415 & $88 \%$ \\
Passive & 54 & $12 \%$ \\
\hline Total & 469 & 100.0 \\
\hline
\end{tabular}

Example 12: While pre-school and elementary-age children are encouraged to draw, soon after starting formal education, students find visual activities replaced by word and number exercises, which are highly ordered and conventionalized forms of expression compared to visual expression

Example 13: In fact, visual thinking and learning are often translated into verbal language in order to convey ideas to others in an understandable way

Table 4 shows that 469 verbs were used in 40 theses (statement of the problem part) semantically, of which $67(27 \%)$ were activity verbs, 67 (27\%) were communication verbs, $40(16 \%)$ were mental verbs, $45(18 \%)$ were verbs of existence or relationship, 18 (7\%) were verbs of facilitation or causation, $11(4 \%)$ were verbs of simple occurrence, and $2(1 \%)$ were aspectual verbs.

Table 4

Frequency of semantic meaning of verbs

\begin{tabular}{lcc}
\hline & Frequency & Percentage \\
\hline Activity & 67 & 27 \\
Aspectual verbs & 2 & 1 \\
Communication verbs & 67 & 27
\end{tabular}

The Study of Syntactic and Semantic features of Verbs in Problem Statement Section of Master Theses 


\begin{tabular}{lcc} 
Mental verb & 40 & 16 \\
Verb of simple occurrence reporting & 11 & 4 \\
Verbs of existence relationship & 45 & 18 \\
Verbs of facilitation or causation & 18 & 7 \\
\hline Total & 250 & 100.0 \\
\hline
\end{tabular}

The most common verb type was "mental" in both corpora. The greater use of mental verbs in the ELT theses analysed might be imposed by the rhetorical functions of ELT theses moves and steps. In both corpora, these kinds of verbs were used to report earlier studies and state the aim of the study. Such verbs are commonly used in sentences that presents aim or information, claim or argument from literature as shown in Examples 14-17.

Example 14: The relationship between the native-English-speaking university teachers' perceptions of English teaching with the importance in cultural learning and communication, and their instructional practice needs to be investigated regarding English-as-a-foreign-language.

Example 15: this study examined the preparation of future SLW teachers in master's level academic programs in the teaching of English as a Second Language (MATESOL) and its related fields.

Example 16: African American audiences of post-Civil Rights Era Black genre films believe that the films are an oppositional cultural practice to mainstream status quo American genre films.

Example 17: Though no shortage of studies on alternative preparation programs exists (Darling-Hammond, Chung, \& Freelow, 2002; Grossman \& Loeb, 2008), too little is known about the intersection of secondary level mainstream AC teachers and linguistically diverse students.

\section{Conclusion}

This study examined the types of verbs used in "PS" section of ELT theses written by native writers of English as well as the semantic and syntactic features of the verbs used. The results concerning syntactic structure indicated that in ELT theses, the simple present was the predominant tense. This appears to be because writers present facts, define entities, state aims and outline purposes in theses; thus, the use of this tense is motivated by the rhetorical functions of moves and steps of theses. To conclude, writers need to be aware that tenses can help editors and reviewers to judge the skill and knowledge of the writer, and they can play a pivotal role in the realisation of moves and steps within the theses. Regarding voice, the active voice was predominant, which may be expected given that it is the preferred tone in thesis writing. This is especially evident in the statement of the problem section, where writers have to claim the centrality, significance and importance of the study. This requires creating structures where the subject is the performer of actions. Such structures are the norm in thesis writing, and this needs to be highlighted for novice writers. 
Concerning the semantic meaning of verbs, three kinds of verbs were used especially frequently: mental, activity, communication, and existence or relationship verbs. These kinds of verbs are helpful in realising the steps and moves of theses; thus, writers need to be aware that tenses of verbs can help editors and reviewers to judge the skill and knowledge of the writer, and they can play a pivotal role in the realisations of moves and steps within the thesis. The findings of this study may act as a good guide to help postgraduate students to write PS section by selecting verbs that are correct syntactically and semantically. Moreover, the findings of this study could be used to help syllabus designers and instructors to include guide on how to select verbs in writing PS in textbooks and teaching.

\section{References}

Axelrod, R., \& Cooper, C. (2001). The St. Martin's guide to writing $\left(6^{\text {th }}\right.$ ed.). New York, NY: St Martin's.

Beason, L., \& Lester, M. (2000). A common sense guide to grammar and usage $\left(2^{\text {nd }}\right.$ ed.). Boston, MA: Bedford/St Martin's.

Biber, D., Johansson, S., Leech, G., Conrad, S., Finegan, E., \& Quirk, R. (1999). Longman grammar of spoken and written English (Vol. 2). Cambridge, MA: MIT Press.

Creswell, J. (2012). Educational research: Planning, conducting, and evaluating qualitative research (4th ed.). New York, NY: Pearson Education Company.

Hinkel, E. (2004). Tense, aspect and the passive voice in L1 and L2 academic texts. Language Teaching Research, 8 (5), 5-29.

Holmes, J. (1983). Speaking English with the appropriate degree of conviction. Learning and teaching languages for communication: Applied linguistics perspectives, 100-121.

Holmes, J. (1988). Doubt and certainty in ESL textbooks. Applied linguistics, 9(1), 2144.

Ibrahim, N., \& Nambiar, R. M. (2011). What is the problem with the statement of problem? : The case of postgraduate international students and the introductory sections of a project paper. Procedia Social and Behavioral Sciences, 59, 1713-1717.

Jalilifar, A., Firuzmand, S., \& Roshani, S. (2011). Genre analysis of problem statement sections of MA proposals and theses in Applied Linguistics. Language, Society and Culture, 33, 85-93.

Karbach, J. (1987). Using Toulmin's model of argumentation. Journal of Teaching Writing, 6(1), 81-91.

Metoyer-Duran, C., \& Hernon, P. (1994). Problem statements in research proposals and published research: A Case Study of Researchers' Viewpoints. Library \& Information Science Research, 16(2), 105-118.

Mohsenzadeh \& Ebrahimi (2017). Verbs in applied linguistics research article introductions: Semantic and syntactic analysis. International Journal of Foreign Language Teaching \& Research, 5(17), 1-9

Nenty, H. J. (2009). Writing a quantitative research thesis. International J. Educ. Sci. $1(1), 19-32$. 
Nimehchisalem, V., Tarvirdizadeh, Z., Sayed Paidary, S., and Hussin, N. (2016). Rhetorical moves in problem statement section of Iranian EFL postgraduate students' theses. Advances in Language and Literary Studies, 7(4), 1-8

Stubbs, M. (1985). Grammar, text, and ideology: computer-assisted methods in the linguistics of representation. Applied Linguistics, 9(2), 201-223

Swales, J. (1990). Genre analysis: English in academic and research settings. Cambrige, England: Cambridge University Press.

Waard, A. \& Pander Maat, H. (2012). Verb form indicates discourse segment type in biological research papers: Experimental evidence. Journal of English for Academic Purposes, 11(1), 357-366.

Zhang, G. (2015). It is suggested that... or it is better to...? Forms and meanings of subject it-extraposition in academic and popular writing. Journal of English for Academic Purposes, 20, 1-13. 